\title{
Complement in Lupus Nephritis: New Perspectives
}

\author{
Lihua Bao $^{\text {a }}$ Patrick N. Cunningham ${ }^{a}$ Richard J. Quigg ${ }^{b}$

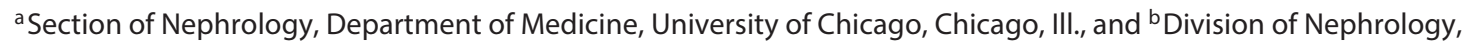 \\ University at Buffalo School of Medicine, Buffalo, N.Y., USA
}

\section{Key Words}

Animal model · Complement · Lupus nephritis · Systemic lupus erythematosus · Therapy

\begin{abstract}
Background: Systemic lupus erythematosus (SLE) is an autoimmune disorder caused by loss of tolerance to self-antigens, the production of autoantibodies and deposition of complement-fixing immune complexes (ICs) in injured tissues. SLE is characterized by a wide range of clinical manifestations and targeted organs, with lupus nephritis being one of the most serious complications. The complement system consists of three pathways and is tightly controlled by a set of regulatory proteins to prevent injudicious complement activation on host tissue. The involvement of the complement system in the pathogenesis of SLE is well accepted; yet, its exact role is still not clear. Summary: Complement plays dual roles in the pathogenesis of SLE. On the one hand, the complement system appears to have protective features in that hereditary homozygous deficiencies of classical pathway components, such as $\mathrm{C} 1 \mathrm{q}$ and $\mathrm{C} 4$, are associated with an increased risk for SLE. On the other hand, IC-mediated activation of complement in affected tissues is clearly evident in both experimental and human SLE along with pathological features that are logical consequences of complement activation. Studies in genetically altered mice have shown that lack of complement inhibitors, such as complement factor $\mathrm{H}$ (CFH) or decay-accelerating factor (DAF) accelerates the de-
\end{abstract}

velopment of experimental lupus nephritis, while treatment with recombinant protein inhibitors, such as Crry-lg, CR2Crry, CR2-DAF and CR2-CFH, ameliorates the disease development. Complement-targeted drugs, including soluble complement receptor 1 (TP10), C1 esterase inhibitor and a monoclonal anti-C5 antibody (eculizumab), have been shown to inhibit complement safely, and are now being investigated in a variety of clinical conditions. Key Messages: SLE is an autoimmune disorder which targets multiple systems. Complement is centrally involved and plays dual roles in the pathogenesis of SLE. Studies from experimental lupus models and clinical trials support the use of complementtargeted therapy in the treatment of SLE.

두 2015 S. Karger AG, Base

\section{Introduction}

The complement system is an important part of innate immunity which defends the host against infectious microorganisms, clears immune complexes (ICs) and dead cells, and serves as a bridge between the innate and adaptive immunity [1]. Complement can be activated through classical, alternative and mannose-binding lectin (MBL) pathways, each with different initiators (shown schematically in fig. 1).

The classical pathway is activated when $\mathrm{C} 1 \mathrm{q}$ of $\mathrm{C} 1$ binds with high avidity to the Fc portion of immunoglobulin M (IgM; $\mathrm{CH} 3$ domain) or IgG ( $\mathrm{CH} 2$ domain) in ICs.

\section{KARGER 125}

(c) 2015 S. Karger AG, Base

2296-9381/15/0012-0091\$39.50/0

E-Mail karger@karger.com

www.karger.com/kdd
Lihua Bao

Section of Nephrology, Department of Medicine

University of Chicago, 5841 S. Maryland Ave. MC5100

Chicago, IL 60637 (USA)

E-Maillbao@medicine.bsd.uchicago.edu 
Fig. 1. The complement system. Shown are the three activation pathways - classical, MBL and alternative pathways - and the common intermediates of activation C3 and $\mathrm{C} 5$ convertases. The main effectors of complement's actions C1q, C3a, C3b, C5a and C5b-9 are indicated. Regulatory proteins are in the yellow circles, as is anti-C5 antibody.

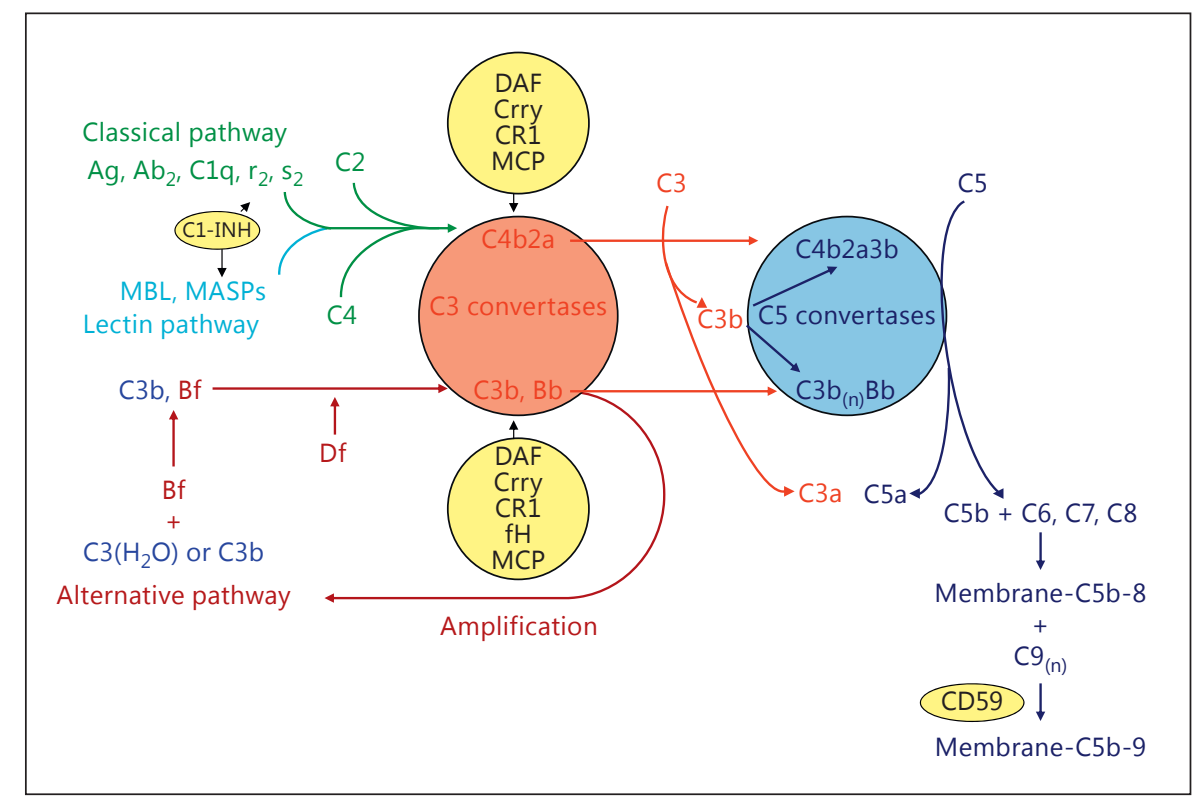

Besides Igs, C1q also binds and facilitates the removal of apoptotic cells, which provides it an important role in immune tolerance. The binding of $\mathrm{Clq}$ to its target triggers its conformational change and self-activation of $\mathrm{Clr}$, followed by the activation of $\mathrm{C} 1 \mathrm{~s}$ [2]. Activated $\mathrm{C} 1$ cleaves both $\mathrm{C} 4$ and $\mathrm{C} 2$ to generate $\mathrm{C} 4 \mathrm{a} / \mathrm{C} 4 \mathrm{~b}$ and $\mathrm{C} 2 \mathrm{a} / \mathrm{C} 2 \mathrm{~b}$. C4b2a acts as a $\mathrm{C} 3$ convertase which cleaves and activates $\mathrm{C} 3$.

The alternative pathway is spontaneously activated by a $\mathrm{C} 3$ conformation change, which occurs slowly but continuously to generate hydrolyzed $\mathrm{C} 3\left[\mathrm{C} 3\left(\mathrm{H}_{2} \mathrm{O}\right)\right] . \mathrm{C} 3\left(\mathrm{H}_{2} \mathrm{O}\right)$ then binds factor $\mathrm{B}$ in the fluid phase. Upon factor B's cleavage by factor $\mathrm{D}$ (adipsin), an initial C3 convertase $\mathrm{C} 3\left(\mathrm{H}_{2} \mathrm{O}\right) \mathrm{Bb}$ is formed, which can be stabilized by properdin and amplify itself to form $\mathrm{C} 3 \mathrm{bBb}$, the alternative pathway C3 convertase [1].

The binding of MBL to terminal carbohydrate groups on certain microbes leads to the activation of the MBLassociated serine proteases (MASP). Activated MASP cleaves $\mathrm{C} 4$ to $\mathrm{C} 4 \mathrm{a}$ and $\mathrm{C} 4 \mathrm{~b}$. Immobilized $\mathrm{C} 4 \mathrm{~b}$ induces the binding of $\mathrm{C} 2$ which is also cleaved by MASP and generates the $\mathrm{C} 4 \mathrm{~b} 2 \mathrm{a} \mathrm{C} 3$ convertase [1].

Irrespective of the pathway of activation, cleavage of C3 and C5 ultimately occurs, with the generation of the $\mathrm{C} 3 \mathrm{a}$ and $\mathrm{C} 5 \mathrm{a}$ anaphylatoxins, C3b opsonins and C5b to start the nonenzymatic assembly of the C5b-9 membrane attack complex, which can result in cellular death or activation after membrane insertion [3].

To prevent injury to host tissues, complement activation is strictly regulated by a number of plasma and cell membrane-associated proteins (fig. 1) [1]. Decay-accel- erating factor (DAF) is a glycosylphosphatidylinositol (GPI)-anchored membrane protein, which binds $\mathrm{C} 3 \mathrm{~b}$ and $\mathrm{C} 4 \mathrm{~b}$ and accelerates the decay of $\mathrm{C} 3$ (C4b2a in classical pathway and $\mathrm{C} 3 \mathrm{bBb}$ in alternative pathway) and $\mathrm{C} 5$ (C4b2a3b in classical pathway and C3bBb3b in alternative pathway) convertases [4]. CR1 is a single-chain transmembrane glycoprotein which has the combined functions of DAF and membrane cofactor protein (MCP). It accelerates the decay of $\mathrm{C} 3$ and $\mathrm{C} 5$ convertases like DAF, and it also serves as a cofactor for factor I-mediated inactivation of C3b and C4b into iC3b and iC4b like MCP [5].

The plasma proteins $\mathrm{C} 4 \mathrm{bp}$ and complement factor $\mathrm{H}$ (CFH) also have cofactor activity for factor I-mediated inactivation of plasma $\mathrm{C} 4 \mathrm{~b}$ and $\mathrm{C} 3 \mathrm{~b}$ in the classical and alternative pathways, respectively. Specific to rodents is the $65-\mathrm{kDa}$ rodent complement regulatory protein, more commonly referred to as CR1-related gene/protein y (Crry) which has combined decay-accelerating and factor I cofactor activity for C3b and C4b, similar to CR1 [6]. Lastly, at either 'end' of the complement cascades are C1 inhibitor (C1-INH) and CD59, which inhibit C1 activation and C5b-9 formation, respectively $[7,8]$.

The involvement of the complement system in the pathogenesis of a number of autoimmune diseases including systemic lupus erythematosus (SLE) is well accepted, yet its exact role is still not clear. On the one hand, hereditary deficiencies of early classical pathway complement components predispose patients to SLE. On the other hand, activation of complement by ICs is certainly a prominent feature in SLE that promotes tissue injury. There- 
fore, an imbalance of the complement system in either direction and the respective roles of the classical and alternative pathways can have complex effects on the disease phenotype. The current review will discuss the dual roles of complement in SLE, and in particular in lupus nephritis.

\section{The Role of the Complement System in Human SLE}

The pathogenic roles of complement activation in human SLE were indicated from years of clinical observations: low total complement hemolytic activity $\left(\mathrm{CH}_{50}\right)$ and decreased C3 and C4 levels have been found in about $75 \%$ of SLE patients with focal nephritis and $90 \%$ in patients with diffuse nephritis [9]. Additionally, the co-localization of Ig isotypes IgG, IgA and IgM with C1q, C4 and C3 (and C5b-9; the so called 'full house' pattern) in the glomeruli is almost exclusively present in glomeruli of patients with lupus nephritis [10]. Finally, complement split products such as C3d and C5b-9 can also be detected in the urine of SLE patients [11].

While frequent mutations in $\mathrm{CFH}$ and CD46 (which encodes MCP) found in atypical hemolytic uremic syndrome (aHUS) are not associated with lupus nephritis, SLE patients carrying these mutations do have an earlier onset of lupus nephritis [12]. SLE patients with lymphopenia and neutropenia were found to have lower levels of DAF and CD59 on neutrophils, and SLE patients with anemia had lower expression of CD59 and CR1 on erythrocytes, and the expression is correlated with disease activity [13]. In neutrophils from SLE patients, IC downregulates the levels of CR1 transcripts, both directly and indirectly via inhibiting IFN- $\gamma$-induced CR1 expression, an example of how lupus activity affects CR1 expression [14]. Nonetheless, higher CR1 expression on SLE patient leukocytes indicates a better prognosis [15], while lower leukocyte MCP expression is associated with lupus remission [16]. These findings not only suggest the pivotal roles of the complement system in the pathogenesis of SLE, but may also potentially provide noninvasive markers for the disease activity.

Impaired IC handling plays an important role in the pathogenesis in lupus nephritis. Since the complement system is required at all steps of normal IC metabolism, any number of alterations can lead to pathological glomerular IC accumulation, particularly in conditions of IC excess, as in SLE. Studies have shown the association of SLE with low levels of CR1 on erythrocytes, a key site of binding and transferring IC to the mononuclear phagocyte system [17], suggesting that a defective erythrocyte/ IC-clearing system may be related to SLE pathogenesis.
In contrast to the widespread belief that generation of complement activation products in kidney and other disease sites is proinflammatory, patients with homozygous deficiencies of the $\mathrm{C} 1$ proteins $(\mathrm{C} 1 \mathrm{q}$ or $\mathrm{C} 1 \mathrm{r} / \mathrm{s})$ or $\mathrm{C} 4$ have a high prevalence $(>80 \%)$ of autoantibodies and SLE-like disease [18]. Successful treatment of C1q-deficient SLE patients with fresh frozen plasma or hematopoietic stem cell transplantation has also been reported $[19,20]$. It is also noteworthy that in SLE patients, anti-C1q antibodies are associated with proliferative lupus nephritis, and its levels may indicate renal disease activity [21]. More recently, it was reported that in the presence of sera from individuals deficient in $\mathrm{C} 1 \mathrm{q}, \mathrm{C} 4, \mathrm{C} 2$ or $\mathrm{C} 3$, phagocytosis of apoptotic cells was decreased compared with studies using normal sera, indicating important roles of all these complement classical pathway components in clearance of apoptotic and necrotic cells [22]. Circulating cell-derived microparticles in patients with SLE carry more IgG, IgM and $\mathrm{Clq}$, and IgG-bearing microparticles are associated with autoantibodies and complement activation [23]. Interestingly, in the very rare cases of homozygous deficiency of $\mathrm{C} 3$, the most critical protein that affects all three pathways of complement activation, there is no association with SLE [24].

Complement also plays important roles in thrombotic complications associated with SLE. The risk of thrombosis is particularly high in SLE patients with antiphospholipid autoantibodies (aPL). One explanation is that aPLcontaining ICs bind to platelets which can subsequently activate the classical complement pathway, as supported by the fact that SLE patients have increased levels of C1q, $\mathrm{C} 3 \mathrm{~d}$ and $\mathrm{C} 4 \mathrm{~d}$ on their platelets, especially in patients with a history of venous thrombosis. Sera from SLE patients with aPL antibodies has a higher capacity to activate the classical pathway on heterologous platelets [25]. Though $\mathrm{C} 1 \mathrm{q}$ and C4d deposition on platelets is not specific for SLE, this is associated with venous thrombosis [26]. One study also suggests that small dense HDL particles may activate the complement system and are related to subclinical atherosclerosis in SLE patients [27].

\section{Studies of Complement in Experimental Lupus Models}

Two of the best studied murine models that spontaneously develop lupus-like syndromes are the $\mathrm{F}_{1}$ cross between New Zealand Black and New Zealand White mice $(\mathrm{NZB} / \mathrm{W})$ and the MRL/MpJ-Tnfrsf6 ${ }^{\text {pr/lpr } / J}$ (MRL/lpr) strain [28]. Similar to the female predominance in hu- 
mans, only female NZB/W mice develop SLE. Both models have $\mathrm{B}$ cell hyperactivity, autoantibodies, hypocomplementemia, circulating and glomerular-bound ICs, and severe nephritis. As in humans, there is plenty of circumstantial evidence that complement activation is actively involved in the pathogenesis of glomerular disease in these mice. In early stages (4 and 5 months in MRL/lpr and $\mathrm{NZB} / \mathrm{W}$ mice, respectively), granular deposition of mouse IgG, IgA, IgM and C3 is present largely in the mesangium, coincident with histopathology showing mesangial proliferation. As the disease progresses, there are glomerular capillary wall IC deposits, proliferation of intrinsic endothelial and mesangial cells, and infiltration with inflammatory cells. Eventually, crescent formation (more often in $\mathrm{MRL} / \mathrm{lpr}$ mice) and glomerulosclerosis (more often in $\mathrm{NZB} / \mathrm{W}$ mice) occur, and mice die of renal failure [28].

The manipulation of individual complement proteins through genetic techniques in lupus mouse strains and functional inhibition through the use of specific antibodies or antagonists have provided considerable insight into how complement is involved in this disease. Given that $\mathrm{C} 3$ is the common point connecting all three pathways in complement activation and is tightly regulated naturally, many of the studies in lupus mice have concentrated on activators and regulators of $\mathrm{C} 3$.

DAF is a ubiquitously expressed GPI-anchored membrane protein that inhibits $\mathrm{C} 3$ activation through all pathways by inhibiting formation and accelerating decay of the $\mathrm{C} 3 / \mathrm{C} 5$ convertase [4]. The relevance of DAF to lupus is suggested by the fact that DAF-deficient MRL/lpr mice had exacerbated lymphoproliferation, anti-chromatin autoantibody production and dermatitis, particularly evident in females, while nephritis appeared to be unaffected [29]. Furthermore, DAF-deficient MRL/lpr mice also deficient in C3 developed comparable lymphadenopathy, splenomegaly and anti-chromatin autoantibodies to what is seen in the complement-sufficient mice, suggesting the protective effect of DAF in MRL/lpr autoimmunity is complement independent. DAF-sufficient MRL/lpr chimeras with DAF-deficient MRL/lpr bone marrow developed significantly attenuated dermatitis compared with that in DAF-deficient MRL/lpr chimeras with DAF-sufficient MRL/lpr bone marrow, indicating that the protective effect of DAF on dermatitis is attributable to local expression [30]. The exacerbated dermatitis can be explained by the fact that DAF is strongly expressed in the skin while Crry is not.

Like human CR1, Crry is an intrinsic membrane complement inhibitor that inhibits $\mathrm{C} 3$ convertases of all pathways with combining activities of human DAF and MCP
[6]. Given that the Crry-deficient mice generated by Xu et al. [31] have complete embryonic lethality from unrestricted maternal complement activation, a straightforward Crry-deficient murine lupus model is not available. The critical role of Crry in regulating complement in the kidney came from our study of transplantation of $\mathrm{Crry}^{-/-} \mathrm{C}^{-/-}$kidneys into wild-type hosts. Due to the lack of Crry, there was marked inflammation in the tubulointerstitium which led to complete failure of the transplanted kidney within weeks (while the appropriate controls, including wild-type kidneys transplanted into wild-type or $\mathrm{Crry}^{-/-} \mathrm{C3}^{-/-}$mice remained normal) [32]. On the other hand, transgenic mice developed by our group that overexpressed a soluble form of Crry had less severe lupus nephritis as determined by BUN and albuminuria measurements when crossed into the MRL/lpr strain. Since the spontaneous mortality in lupus mice is largely due to kidney disease, this translated into prolonged survival, while the underlying abnormal autoimmunity was not affected [33]. To make this complement inhibition more applicable to human SLE treatment, a recombinant soluble form of Crry (Crry-Ig) was also used in MRL/lpr mice. In chronic usage from early in the autoimmune disease until the end stage, inhibited complement activation by Crry-Ig ameliorated lupus nephritis [34]. Interestingly, transcript profiling experiments showed that excessive matrix components such as collagens I, III, IV and VI were overexpressed in control MRL/lpr mice, which could be suppressed by complement inhibition with Crry-Ig. Potential explanations for these phenomena include Crry-Ig-mediated reductions in connective tissue growth factor and TGF- $\beta_{1}$ expression, suggesting these profibrotic mediators are downstream of complementinduced injury and contribute to the progressive glomerulosclerosis in MRL/lpr mice [35].

In both human and experimental SLE, CR1/CR2 expression decreases over time, suggesting that this plays a role in disease $[36,37]$. Yet, MRL/lpr mice deficient in CR1/ CR2 had significantly lower levels of total IgG3 and specific IgG3 rheumatoid factor, supporting the role of CR1/ $\mathrm{CR} 2$ in the production of IgG3 in response to autoantigens. Nonetheless, this decrease of IgG3 autoantibodies did not lead to a reduction in features of lupus nephritis [38].

C4bp is a major soluble complement inhibitor of the classical pathway. Elevated serum levels of C4bp in SLE patients suggested its involvement in this disease [39]. More detailed studies addressing this possibility were performed by the Braun group, using a C4bp-deficient $\mathrm{MRL} / \mathrm{lpr}$ mouse model. While serum $\mathrm{C} 4$ levels are lower in MRL/lpr mice compared with normal C57BL/6 mice, 
starting as early as 3 weeks of age (i.e. prior to autoimmune disease), surprisingly, deficiency of C4bp affected neither serum C4 levels nor the classical pathway hemolytic activity. With an unaffected complement classical pathway, C4bp deficiency did not lead to a significantly different outcome in these mice, which had similar amounts of glomerular C3 and IgG deposition, glomerulonephritis, tubulointerstitial inflammation, proteinuria and renal function. Moreover, the systemic immune response was not affected by the absence of C4bp in these mice [40]. One explanation for the negligible role of C4bp in lupus development in MRL/lpr mice is that the extensively activated classical pathway in this model simply overwhelms the absence of C4bp. In this situation, 'a gain of function' of C4bp may reveal more information as purified human C4bp successfully inhibited the classical complement pathway, leading to delayed or reduced disease development in these models [41].

In physiological situations, there is spontaneous continuous low-level alternative pathway activation that is restrained by effective complement regulation. While the traditional thinking is that SLE is induced through ICdirected classical pathway activation, the involvement of the alternative pathway has also been suggested in many studies. Gilkeson and colleagues demonstrated that complement factor B- or complement factor D-deficient $\mathrm{MRL} / \mathrm{lpr}$ mice had reduced glomerular C3 deposition associated with less severe glomerular histopathology [42, 43]. These results imply that IC-directed classical pathway activation can recruit the potent alternative pathway to further amplify generation of $\mathrm{C} 3$ and $\mathrm{C} 5$ activation products. $\mathrm{CFH}$-related protein $\mathrm{C}$ is absent in the circulation of MRL/lpr and NZB/W mice before and after the onset of lupus, implying that polymorphic variation may contribute to the development of SLE [44]. Our group demonstrated CFH-deficient MRL/lpr mice had significantly more albuminuria and higher BUN levels than $\mathrm{MRL} / \mathrm{lpr}$ controls, which further led to earlier mortality. $\mathrm{CFH}$-deficient MRL/lpr mice developed severe diffuse lupus nephritis by 12 weeks, with excessive interstitial infiltration of macrophages and neutrophils, and subendothelial and subepithelial immune deposits and extensive podocyte foot process effacement [45]. These findings indicate that loss of $\mathrm{CFH}$ accelerates the development of lupus nephritis and recapitulates the functional and structural features of human disease, distinct from the spontaneous disease in older $\mathrm{CFH}$-deficient mice on mixed backgrounds [46].

C5b-9 deposition was found in diseased lupus kidneys more than 2 decades ago. Yet, compared with extensive studies focusing on $\mathrm{C} 3$ activation and its regulation, fewer studies have been done to investigate the downstream events following C3 activation in the pathogenesis of SLE. Wang et al. [47] used a specific monoclonal antibody to inhibit C5 function in NZB/W mice. Six months of continuous therapy led to a significantly delayed onset of proteinuria, improved renal pathological changes and prolonged survival, implicating a role of products of the terminal complement pathway, C5a and C5b-9, in lupus nephritis. On the other hand, CD59a-deficient MRL/lpr mice had exacerbated skin disease and lymphoproliferation through a complement-independent, autoimmunity-regulatory mechanism, which is conferred by its expression on both bone marrow-derived cell and peripheral tissues [48].

The C3a and C5a anaphylatoxins are generated through complement activation when $\mathrm{C} 3$ and $\mathrm{C} 5$ are activated and cleaved. Increased expression of C3aR was found in glomeruli in human lupus nephritis [49]. C3aR and $\mathrm{C} 5 \mathrm{aR}$ expression were significantly upregulated at both the mRNA and protein levels and accompanied by a wider cellular distribution in MRL/lpr mouse kidneys $[50,51]$. This upregulated expression starts before the onset of kidney disease, supporting the possibility that they may be involved in the development of disease, rather than simply a consequence. Chronic administration of a specific C3aR antagonist (SB290157) led to significantly reduced kidney disease and prolonged survival in MRL/lpr mice [51]. Similarly, when C5a signaling was blocked in our studies with a specific antagonist [50] or in those by Wenderfer et al. [52] through gene targeting, MRL/lpr mice animals displayed attenuated renal disease and prolonged viability. The effects of blocking $\mathrm{C} 3 \mathrm{aR}$ and $\mathrm{C} 5 \mathrm{aR}$ in lupus mice had certain features in common, including less renal neutrophil and macrophage infiltration, apoptosis and interleukin- $1 \beta$ expression $[50,51]$. Effects on chemokine expression were distinct, with $\mathrm{C} 3 \mathrm{aR}-$ and C5aR-inhibited MRL/lpr mice having reduced CCL5 (RANTES) and CXCL2 (MIP-2) expression, respectively. C3aR-inhibited mice also had increased phosphorylation of protein kinase B (Akt), which we considered suggestive that $\mathrm{C} 3 \mathrm{aR}$ signals promote renal cell apoptosis through an Akt pathway [51]. In C5aR-deficient MRL/lpr mice, there was a reduction in $\mathrm{CD} 4+\mathrm{T}$ cell renal infiltration, lower titers of anti-double-stranded DNA antibodies and inhibition of interleukin-12 p20 and IFN- $\gamma$ production, suggesting that Th1 responses are important to link C5a signaling in lupus nephritis [52]. In contrast, C3aR-deficient $\mathrm{MRL} / \mathrm{lpr}$ mice had elevated autoantibody titers, more glomerular crescents and more severe intrarenal vasculitis, 
though this did not affect long-term renal injury or survival [53]. The mechanisms of different outcomes between the short-term (by using antagonist) and the longterm (by using gene targeting) blockade of C3aR signaling in this lupus model still need to be clarified. This may be due to the fact that the particular $\mathrm{C} 3 \mathrm{aR}$ antagonist (SB290157) used in this study has a partial agonist activity as well [54].

Since C3 is the converging point for all three complement pathways, alterations in $\mathrm{C} 3$ activation through manipulating its regulators, such as Crry or DAF, or blockade of the effects of $\mathrm{C} 3$ activation with inhibitors of $\mathrm{C} 3 \mathrm{aR}$, $\mathrm{C} 5 \mathrm{aR}$ or $\mathrm{C} 5$ have shown $\mathrm{C} 3$ activation is an important factor in the development of SLE. Surprisingly, C3 deficiency does not affect the development of nephritis in $\mathrm{MRL} / \mathrm{lpr}$ mice, while glomerular IgG deposition is significantly increased [55]. This study is consistent with the important role of complement, and in particular $\mathrm{C} 3$, in the clearance of ICs [56]. The finding that homozygous deficiency of early components of the classical pathway other than C3 predisposes to SLE suggests that the physiological functions of these molecules are protective in SLE. While the exact mechanism is still unknown, studies found that mice with generated $\mathrm{C} 1 \mathrm{q}$ and $\mathrm{C} 4$ deficiencies had impaired ability to clear apoptotic debris [57], leading to the accumulation of potentially immunogenic autoantigens and initiation of an autoimmune reaction in the right genetic setting. C1q-deficient mice had increased mortality and higher titers of autoantibodies, with $25 \%$ of the mice developing glomerulonephritis, characterized by glomerular IC deposits and apoptotic debris [58]. Further work suggests that $\mathrm{C} 1 \mathrm{q}$ and $\mathrm{DNase} 1$ are important in the degradation of chromatin derived from necrotic cells [59]. It was also found that the IgG autoantibodies were responsible for the inhibition of macrophage removal of apoptotic cells through $\mathrm{C} 3$ deposition in $\mathrm{MRL} / \mathrm{lpr}$ and $\mathrm{NZB} / \mathrm{W}$ mice [60]. On the other hand, C3 deposition on nucleic acids is significantly reduced when dsDNA-specific IgG autoantibodies are present in the serum, which increase as disease progresses in MRL/lpr mice [61].

In both human and experimental lupus nephritis, the complement system has a dual role. The classic pathway contributes to its protective role in the clearance of apoptotic material and circulating IC [22, 62]. In theory, chronic systemic complement inhibition may increase circulating IC and exacerbate disease [34]. To selectively target the desired complement regulator to the site of tissue injury, Tomlinson and colleagues used CR2 as the 'guide' of complement inhibitors, given that sites of complement activation are 'marked' by the presence of C3d [63], and CR2 has natural affinity for $\mathrm{C} 3 \mathrm{~d}$. Thus, low doses of chimeric CR2-DAF and CR2-CD59 efficiently protected target cells from complement attack [64]. CR2-DAF was targeted to the glomerulus in lupus nephritis while soluble DAF failed [64]. Long-term (8-week) treatment of diseased MRL/lpr mice with low doses of CR2-Crry and CR2-CFH provided significant complement inhibition locally in the lupus glomerulus, which conferred significant reduction of proteinuria, as well as prolonged survival in these mice $[65$, 66]. CR2-CFH also significantly reduced glomerulonephritis [66]. The fact that selective alternative pathway inhibition by $\mathrm{CR} 2-\mathrm{CFH}$ provided significant reduction in glomerulonephritis while total complement inhibition with CR2-Crry did not supports that the alternative and classical pathways of complement has distinct roles in the pathogenesis of lupus nephritis [66, 67].

Investigations of complement activation in lupus nephritis suggested not only potential therapies, but also diagnostic and monitoring tools. Using CR2-targeted MRI, glomerular $\mathrm{C} 3 \mathrm{~b} / \mathrm{iC} 3 \mathrm{~b} / \mathrm{C} 3 \mathrm{~d}$ deposition in $\mathrm{MRL} / \mathrm{lpr}$ mice was found to increase with disease activity, suggesting its usage as a marker of onset and severity of lupus glomerulonephritis, which could be used to monitor the disease course and its response to therapy repeatedly and noninvasively [68].

\section{What We Have Learned from Animals Can Be Used in the Treatment of Humans}

Strategies to manipulate the complement system in different human diseases have followed from successful animal studies, including those using recombinant intrinsic complement regulators and blocking antibodies. In addition to the treatment approaches indicated in studies using experimental models discussed above, we will focus on several promising therapeutic approaches that have been used in the treatment of human diseases, and may potentially extend to the treatment of human SLE and lupus nephritis.

Soluble CR1 (sCR1) was first developed in 1990, and has both decay accelerator and cofactor activity in classical and alternative complement pathways. A current therapeutic form of soluble CR1 designated as TP10 (Avant Immunotherapeutics, Nedham, Mass., USA) has been used in clinical trials in several human diseases, including acute respiratory distress syndrome [69], ischemia-reperfusion injury in patients undergoing lung transplantation [70] or cardiac surgery [71]. These studies showed that sCR1 was well tolerated, with low development of anti- 
sCR1 antibodies [71]. More recently, soluble CR1 was found to prevent dysregulation of the alternative pathway $\mathrm{C} 3$ convertases in dense deposit disease and C3 glomerulonephritis (C3GN), supporting the clinical trial of soluble CR1 as a treatment for DDD and C3GN [72].

$\mathrm{C} 1$ esterase inhibitor (C1-INH) has been marketed as replacement therapy for hereditary angioedema (HAE) and ischemia-reperfusion injury. Plasma-derived C1INH has shown to be effective in prophylaxis, reducing the frequency of attacks of HAE and shortening the duration of the acute attacks [73]. Recombinant human C1INH also proved to be effective in the treatment of $\mathrm{HAE}$ patients during acute attacks [74]. C1-INH was also reported to successfully ameliorate both complement deposition on RBCs and hemolysis in autoimmune hemolytic anemia [75].

The most extensively used antibody targeting the complement system is a monoclonal antibody that directly binds human $\mathrm{C} 5$ and prevents its cleavage to $\mathrm{C} 5 \mathrm{a}$ and $\mathrm{C} 5 \mathrm{~b}$ as a humanized monoclonal antibody (Eculizumab, Alexion Pharmaceuticals Inc., Cheshire, Conn., USA). In March 2007, Eculizumab (Soliris) was the first and the only US Food and Drug Administration (FDA)-approved complement inhibitor used in the treatment of human diseases. It was approved by the FDA for the treatment of paroxysmal nocturnal hemoglobinuria, an acquired disorder of GPI-linked proteins including DAF and CD59 characterized by spontaneous complement activation and C5b-9-mediated hemolysis. It was subsequently approved for the treatment of aHUS in 2011. Different phase 3 clinical trials showed that eculizumab treatment showed better stabilization of hemoglobin and reduced intravascular hemolysis with significant clinical improvements [76] even with long-term treatment [77]. Eculizumab increases aHUS patients' platelet count, with $80 \%$ of patients achieving thrombotic microangiopathic event-free status [78]. With this beneficial effect of eculi- zumab in aHUS, it is encouraging that a phase 1 trial has shown it is safe, with a prolonged interval of complement inhibition in SLE patients. Moving to the kidney, a multicenter phase 2 trial in the United States in which 122 patients with idiopathic membranous nephropathy were enrolled in a randomized placebo-controlled study of eculizumab has been completed. Unfortunately, there was no difference between treatment and placebo in the primary outcome variable of urinary protein excretion. Because of the short-term treatment strategy in a long-term disease, the study design may have been insufficient to uncover a true therapeutic effect. This is supported by the finding of an apparent benefit in patients enrolled in an open-label extension. Based on the impressive effects of long-term treatment with anti-C5 effects in lupus nephritis in NZB/W lupus mice [47], Furie's group conducted a phase 1 study with eculizumab in 24 patients with SLE. In this single-center, randomized, placebo-controlled, double-blind, dose-ranging trial, patients were given a single intravenous dose of eculizumab or placebo and were followed for 2 months. Only mild adverse events were reported, and complement inhibition for 10 days in the $8 \mathrm{mg} / \mathrm{kg}$ group was observed [79]. We also designed a multicenter phase 2 trial using eculizumab in proliferative lupus nephritis supported by the United States' National Institutes of Health. Unfortunately, after enrollment of our first patient, this study encountered logistical delays and ultimately came to a complete halt. While this reflects the difficulties in clinical trials for a disorder such as lupus nephritis, based on what is known about the pathophysiology, we remain interested in the potential efficacy of this drug in the treatment of lupus nephritis.

\section{Disclosure Statement}

There is no financial conflict of interest affecting any of the authors.

\section{References}

1 Walport MJ: Complement. First of two parts. N Engl J Med 2001;344:1058-1066.

-2 Gaboriaud C, Thielens NM, Gregory LA, Rossi V, Fontecilla-Camps JC, Arlaud GJ: Structure and activation of the $\mathrm{cl}$ complex of complement: unraveling the puzzle. Trends Immunol 2004;25:368-373.

-3 Nicholson-Weller A, Halperin JA: Membrane signaling by complement C5b-9, the membrane attack complex. Immunol Res 1993;12: 244-257.

Complement in Lupus Nephritis
4 Lublin DM, Atkinson JP: Decay-accelerating factor: biochemistry, molecular biology, and function. Annu Rev Immunol 1989;7:35-58.

5 Ahearn JM, Fearon DT: Structure and function of the complement receptors, CR1 (CD35) and CR2 (CD21). Adv Immunol 1989;46:183-219.
-6 Kim YU, Kinoshita T, Molina H, Hourcade D, Seya T, Wagner LM, Holers VM: Mouse complement regulatory protein Crry/p65 uses the specific mechanisms of both human decayaccelerating factor and membrane cofactor protein. J Exp Med 1995;181:151-159.

7 Morgan P, Harris C: Regulation in the Activation Pathways; Complement Regulatory Proteins. San Diego, Academic Press, 1999, pp 41-136. 
8 Morgan P, Harris C: Regulation in the Terminal Pathway; Complement Regulatory Proteins. San Diego, Academic Press, 1999.

-9 Valentijn RM, van Overhagen H, Hazevoet HM, Hermans J, Cats A, Daha MR, van ES LA: The value of complement and immune complex determinations in monitoring disease activity in patients with systemic lupus erythematosus. Arthritis Rheum 1985;28:904-913.

10 Dalmasso AP: Complement in the pathophysiology and diagnosis of human diseases. Crit Rev Clin Lab Sci 1986;24:123-183.

11 Manzi S, Rairie JE, Carpenter AB, Kelly RH, Jagarlapudi SP, Sereika SM, Medsger TA, Ramsey-Goldman R: Sensitivity and specificity of plasma and urine complement split products as indicators of lupus disease activity. Arthritis Rheum 1996;39:1178-1188.

-12 Jönsen A, Nilsson SC, Ahlqvist E, Svenungsson E, Gunnarsson I, Eriksson KG, Bengtsson A, Zickert A, Eloranta ML, Truedsson L, Rönnblom L, Nordmark G, Sturfelt G, Blom AM: Mutations in genes encoding complement inhibitors CD46 and CFH affect the age at nephritis onset in patients with systemic lupus erythematosus. Arthritis Res Ther 2011; 13:R206.

13 Alegretti AP, Schneider L, Piccoli AK, Monticielo OA, Lora PS, Brenol JC, Xavier RM: Diminished expression of complement regulatory proteins on peripheral blood cells from systemic lupus erythematosus patients. Clin Dev Immunol 2012;2012:725684.

-14 Arora V, Mondal AM, Grover R, Kumar A, Chattopadhyay P, Das N: Modulation of CR1 transcript in systemic lupus erythematosus (SLE) by IFN-gamma and immune complex. Mol Immunol 2007;44:1722-1728.

15 Arora V, Grover R, Kumar A, Anand D, Das $\mathrm{N}$ : Relationship of leukocyte CR1 transcript and protein with the pathophysiology and prognosis of systemic lupus erythematosus: a follow-up study. Lupus 2011;20:1010-1018.

16 Biswas B, Kumar U, Das N: Expression and significance of leukocyte membrane cofactor protein transcript in systemic lupus erythematosus. Lupus 2012;21:517-525.

$\checkmark 17$ Ross GD, Yount WJ, Walport MJ, Winfield JB, Parker CJ, Fuller CR, Taylor RP, Myones BL, Lachmann PJ: Disease-associated loss of erythrocyte complement receptors (CR1, C3b receptors) in patients with systemic lupus erythematosus and other diseases involving autoantibodies and/or complement activation. J Immunol 1985;135:2005-2014.

18 Manderson AP, Botto M, Walport MJ: The role of complement in the development of systemic lupus erythematosus. Annu Rev Immunol 2004;22:431-456.

19 Arkwright PD, Riley P, Hughes SM, Alachkar H, Wynn RF: Successful cure of C1q deficiency in human subjects treated with hematopoietic stem cell transplantation. J Allergy Clin Immunol 2014;133:265-267.
20 Mehta P, Norsworthy PJ, Hall AE, Kelly SJ, Walport MJ, Botto M, Pickering MC: SLE with $\mathrm{C} 1 \mathrm{q}$ deficiency treated with fresh frozen plasma: a 10-year experience. Rheumatology (Oxford) 2010;49:823-824.

21 Yin Y, Wu X, Shan G, Zhang X: Diagnostic value of serum anti-C1q antibodies in patients with lupus nephritis: a meta-analysis. Lupus 2012;21:1088-1097.

22 Gullstrand B, Mårtensson U, Sturfelt G, Bengtsson AA, Truedsson L: Complement classical pathway components are all important in clearance of apoptotic and secondary necrotic cells. Clin Exp Immunol 2009;156: 303-311.

23 Nielsen CT, Østergaard O, Stener L, Iversen LV, Truedsson L, Gullstrand B, Jacobsen S, Heegaard NH: Increased IgG on cell-derived plasma microparticles in systemic lupus erythematosus is associated with autoantibodies and complement activation. Arthritis Rheum 2012;64:1227-1236.

24 Degn SE, Jensenius JC, Thiel S: Disease-causing mutations in genes of the complement system. Am J Hum Genet 2011;88:689-705.

25 Lood C, Eriksson S, Gullstrand B, Jönsen A, Sturfelt G, Truedsson L, Bengtsson AA: Increased C1q, C4 and C3 deposition on platelets in patients with systemic lupus erythematosus - a possible link to venous thrombosis? Lupus 2012;21:1423-1432.

26 Lood C, Tydén H, Gullstrand B, Sturfelt G, Jönsen A, Truedsson L, Bengtsson AA: Platelet activation and anti-phospholipid antibodies collaborate in the activation of the complement system on platelets in systemic lupus erythematosus. PLoS One 2014;9:e99386.

27 Parra S, Vives G, Ferré R, González M, Guardiola M, Ribalta J, Castro A: Complement system and small HDL particles are associated with subclinical atherosclerosis in SLE patients. Atherosclerosis 2012;225:224-230.

28 Hahn BH, Kono D: Animal models of SLE; in Wallace DJ, Hahn BH (eds): Dubois' Lupus Erythematosus and Related Syndromes: Expert Consult. Philadelphia, Elsevier Saunders, 2012, pp 190-236.

-29 Miwa T, Maldonado MA, Zhou L, Sun X, Luo HY, Cai D, Werth VP, Madaio MP, Eisenberg RA, Song WC: Deletion of decay-accelerating factor (CD55) exacerbates autoimmune disease development in MRL/lpr mice. Am J Pathol 2002;161:1077-1086.

30 Miwa T, Maldonado MA, Zhou L, Yamada K, Gilkeson GS, Eisenberg RA, Song WC: Decay-accelerating factor ameliorates systemic autoimmune disease in MRL/lpr mice via both complement-dependent and -independent mechanisms. Am J Pathol 2007;170: 1258-1266.

31 Xu C, Mao D, Holers VM, Palanca B, Cheng AM, Molina H: A critical role for murine complement regulator Crry in fetomaternal tolerance. Science 2000;287:498-501.
32 Bao L, Wang Y, Chang A, Minto AW, Zhou J, Kang H, Haas M, Quigg RJ: Unrestricted C3 activation occurs in Crry-deficient kidneys and rapidly leads to chronic renal failure. J Am Soc Nephrol 2007;18:811-822.

33 Bao L, Haas M, Boackle SA, Kraus DM, Cunningham PN, Park P, Alexander JJ, Anderson RK, Culhane K, Holers VM, Quigg RJ: Transgenic expression of a soluble complement inhibitor protects against renal disease and promotes survival in MRL/lpr mice. J Immunol 2002;168:3601-3607.

34 Bao L, Haas M, Kraus DM, Hack BK, Rakstang JK, Holers VM, Quigg RJ: Administration of a soluble recombinant complement $\mathrm{C} 3$ inhibitor protects against renal disease in MRL/lpr mice. J Am Soc Nephrol 2003;14: 670-679.

35 Bao L, Zhou J, Holers VM, Quigg RJ: Excessive matrix accumulation in the kidneys of MRL/lpr lupus mice is dependent on complement activation. J Am Soc Nephrol 2003;14: 2516-2525.

36 Takahashi K, Kozono Y, Waldschmidt TJ, Berthiaume D, Quigg RJ, Baron A, Holers VM: Mouse complement receptors type 1 (CR1;CD35) and type 2 (CR2;CD21): Expression on normal B cell subpopulations and decreased levels during the development of autoimmunity in MRL/lpr mice. J Immunol 1997;159:1557-1569.

37 Wilson JG, Ratnoff WD, Schur PH, Fearon DT: Decreased expression of the C3b/C4b receptor (CR1) and the $\mathrm{C} 3 \mathrm{~d}$ receptor (CR2) on $\mathrm{B}$ lymphocytes and of CR1 on neutrophils of patients with systemic lupus erythematosus. Arthritis Rheum 1986;29:739-747.

38 Boackle SA, Culhane KK, Brown JM, Haas M, Bao L, Quigg RJ, Holers VM: CR1/CR2 deficiency alters IgG3 autoantibody production and IgA glomerular deposition in the MRL/ lpr model of SLE. Autoimmunity 2004;37: 111-123.

39 Barnum SR, Dahlbäck B: C4b-binding protein, a regulatory component of the classical pathway of complement, is an acute-phase protein and is elevated in systemic lupus erythematosus. Complement Inflamm 1990;7: $71-77$.

40 Wenderfer SE, Soimo K, Wetsel RA, Braun MC: Analysis of $\mathrm{C} 4$ and the $\mathrm{C} 4$ binding protein in the MRL/lpr mouse. Arthritis Res Ther 2007;9:R114.

41 Blom AM, Nandakumar KS, Holmdahl R: C4b-binding protein (C4bp) inhibits development of experimental arthritis in mice. Ann Rheum Dis 2009;68:136-142.

42 Elliott MK, Jarmi T, Ruiz P, Xu Y, Holers VM, Gilkeson GS: Effects of complement factor D deficiency on the renal disease of MRL/lpr mice. Kidney Int 2004;65:129-138.

43 Watanabe H, Garnier G, Circolo A, Wetsel RA, Ruiz P, Holers VM, Boackle SA, Colten HR, Gilkeson GS: Modulation of renal disease in MRL/lpr mice genetically deficient in the alternative complement pathway factor B. J Immunol 2000;164:786-794. 
-44 Mehta G, Ferreira VP, Skerka C, Zipfel PF, Banda NK: New insights into disease-specific absence of complement factor $\mathrm{H}$ related protein $\mathrm{C}$ in mouse models of spontaneous autoimmune diseases. Mol Immunol 2014;62: 235-248.

45 Bao L, Haas M, Quigg RJ: Complement factor $\mathrm{H}$ deficiency accelerates development of lupus nephritis. J Am Soc Nephrol 2011;22: 285-295.

-46 Pickering MC, Cook HT, Warren J, Bygrave AE, Moss J, Walport MJ, Botto M: Uncontrolled C3 activation causes membranoproliferative glomerulonephritis in mice deficient in complement factor H. Nat Genet 2002;31: 424-428.

$\checkmark 47$ Wang Y, Hu Q, Madri JA, Rollins SA, Chodera A, Matis LA: Amelioration of lupus-like autoimmune disease in NZB/WF1 mice after treatment with a blocking monoclonal antibody specific for complement component C5. Proc Natl Acad Sci USA 1996;93:8563-8568.

-48 Miwa T, Zhou L, Maldonado MA, Madaio MP, Eisenberg RA, Song WC: Absence of CD59 exacerbates systemic autoimmunity in MRL/lpr mice. J Immunol 2012;189:54345441.

-49 Mizuno M, Blanchin S, Gasque P, Nishikawa K, Matsuo S: High levels of complement C3a receptor in the glomeruli in lupus nephritis. Am J Kidney Dis 2007;49:598-606.

- 50 Bao L, Osawe I, Puri T, Lambris JD, Haas M, Quigg RJ: C5a promotes development of experimental lupus nephritis which can be blocked with a specific receptor antagonist. Eur J Immunol 2005;35:2496-2506.

51 Bao L, Osawe I, Haas M, Quigg RJ: Signaling through up-regulated C3a receptor is key to the development of experimental lupus nephritis. J Immunol 2005;175:1947-1955.

- 52 Wenderfer SE, Ke B, Hollmann TJ, Wetsel RA, Lan HY, Braun MC: C5a receptor deficiency attenuates $\mathrm{T}$ cell function and renal disease in MRLlpr mice. J Am Soc Nephrol 2005;16:3572-3582.

-53 Wenderfer SE, Wang H, Ke B, Wetsel RA, Braun MC: C3a receptor deficiency accelerates the onset of renal injury in the MRL/lpr mouse. Mol Immunol 2009;46:1397-1404.

-54 Mathieu MC, Sawyer N, Greig GM, Hamel M, Kargman S, Ducharme Y, Lau CK, Friesen RW, O’Neill GP, Gervais FG, Therien AG: The C3a receptor antagonist SB 290157 has agonist activity. Immunol Lett 2005; 100:139145.

55 Sekine H, Reilly CM, Molano ID, Garnier G, Circolo A, Ruiz P, Holers VM, Boackle SA, Gilkeson GS: Complement component C3 is not required for full expression of immune complex glomerulonephritis in MRL/lpr mice. J Immunol 2001;166:6444-6451.

56 Sheerin NS, Springall T, Carroll M, Sacks SH: Altered distribution of intraglomerular immune complexes in C3-deficient mice. Immunology 1999;97:393-399.

- 57 Taylor PR, Carugati A, Fadok VA, Cook HT, Andrews M, Carroll MC, Savill JS, Henson
PM, Botto M, Walport MJ: A hierarchical role for classical pathway complement proteins in the clearance of apoptotic cells in vivo. J Exp Med 2000;192:359-366.

58 Botto M, Dell'Agnola C, Bygrave AE, Thompson EM, Cook HT, Petry F, Loos M, Pandolfi PP, Walport MJ: Homozygous C1q deficiency causes glomerulonephritis associated with multiple apoptotic bodies. Nat Genet 1998;19: 56-59.

59 Gaipl US, Beyer TD, Heyder P, Kuenkele S, Böttcher A, Voll RE, Kalden JR, Herrmann M: Cooperation between C1q and DNase I in the clearance of necrotic cell-derived chromatin. Arthritis Rheum 2004;50:640-649.

-60 Kenyon KD, Cole C, Crawford F, Kappler JW, Thurman JM, Bratton DL, Boackle SA, Henson PM: IgG autoantibodies against deposited C3 inhibit macrophage-mediated apoptotic cell engulfment in systemic autoimmunity. J Immunol 2011;187:2101-2111.

61 Papp K, Végh P, Tchorbanov A, Vassilev T, Erdei A, Prechl J: Progression of lupus-like disease drives the appearance of complementactivating IgG antibodies in MRL/lpr mice. Rheumatology (Oxford) 2010;49:2273-2280.

62 Schifferli JA, Ng YC, Peters DK: The role of complement and its receptor in the elimination of immune complexes. N Engl J Med 1986;315:488-495.

63 Thurman JM, Kulik L, Orth H, Wong M, Renner B, Sargsyan SA, Mitchell LM, Hourcade DE, Hannan JP, Kovacs JM, Coughlin B, Woodell AS, Pickering MC, Rohrer B, Holers VM: Detection of complement activation using monoclonal antibodies against C3d. J Clin Invest 2013;123:2218-2230.

64 Song H, He C, Knaak C, Guthridge JM, Holers VM, Tomlinson S: Complement receptor 2-mediated targeting of complement inhibitors to sites of complement activation. J Clin Invest 2003;111:1875-1885.

65 Atkinson C, Qiao F, Song H, Gilkeson GS, Tomlinson S: Low-dose targeted complement inhibition protects against renal disease and other manifestations of autoimmune disease in MRL/lpr mice. J Immunol 2008; 180:12311238 .

66 Sekine H, Kinser TT, Qiao F, Martinez E, Paulling E, Ruiz P, Gilkeson GS, Tomlinson S: The benefit of targeted and selective inhibition of the alternative complement pathway for modulating autoimmunity and renal disease in MRL/lpr mice. Arthritis Rheum 2011; 63:1076-1085.

67 Sekine H, Ruiz P, Gilkeson GS, Tomlinson S: The dual role of complement in the progression of renal disease in NZB/W F(1) mice and alternative pathway inhibition. Mol Immunol 2011;49:317-323.

68 Sargsyan SA, Serkova NJ, Renner B, Hasebroock KM, Larsen B, Stoldt C, McFann K, Pickering MC, Thurman JM: Detection of glomerular complement C3 fragments by magnetic resonance imaging in murine lupus nephritis. Kidney Int 2012;81:152159.
69 Zimmerman JL, Dellinger RP, Straube RC, Levin JL: Phase I trial of the recombinant soluble complement receptor 1 in acute lung injury and acute respiratory distress syndrome. Crit Care Med 2000;28:3149-3154.

70 Keshavjee S, Davis RD, Zamora MR, de Perrot M, Patterson GA: A randomized, placebocontrolled trial of complement inhibition in ischemia-reperfusion injury after lung transplantation in human beings. J Thorac Cardiovasc Surg 2005; 129:423-428.

71 Lazar HL, Bokesch PM, van Lenta F, Fitzgerald C, Emmett C, Marsh HC, Ryan U; OBE and the TP10 Cardiac Surgery Study Group: Soluble human complement receptor 1 limits ischemic damage in cardiac surgery patients at high risk requiring cardiopulmonary bypass. Circulation 2004;110:II274-II279.

72 Zhang Y, Nester CM, Holanda DG, Marsh HC, Hammond RA, Thomas LJ, Meyer NC, Hunsicker LG, Sethi S, Smith RJ: Soluble CR1 therapy improves complement regulation in C3 glomerulopathy. J Am Soc Nephrol 2013; 24:1820-1829.

73 Craig TJ, Levy RJ, Wasserman RL, Bewtra AK, Hurewitz D, Obtułowicz K, Reshef A, Ritchie B, Moldovan D, Shirov T, Grivcheva-Panovska V, Kiessling PC, Keinecke HO, Bernstein JA: Efficacy of human C1 esterase inhibitor concentrate compared with placebo in acute hereditary angioedema attacks. J Allergy Clin Immunol 2009;124:801-808.

74 Riedl MA, Levy RJ, Suez D, Lockey RF, Baker JW, Relan A, Zuraw BL: Efficacy and safety of recombinant $\mathrm{C} 1$ inhibitor for the treatment of hereditary angioedema attacks: a North American open-label study. Ann Allergy Asthma Immunol 2013;110:295-299.

75 Wouters D, Stephan F, Strengers P, de Haas M, Brouwer C, Hagenbeek A, van Oers $M H$, Zeerleder S: C1-esterase inhibitor concentrate rescues erythrocytes from complementmediated destruction in autoimmune hemolytic anemia. Blood 2013;121:1242-1244.

76 Brodsky RA, Young NS, Antonioli E, Risitano AM, Schrezenmeier H, Schubert J, Gaya A, Coyle L, de Castro C, Fu CL, Maciejewski JP, Bessler M, Kroon HA, Rother RP, Hillmen P: Multicenter phase 3 study of the complement inhibitor eculizumab for the treatment of patients with paroxysmal nocturnal hemoglobinuria. Blood 2008;111:1840-1847.

77 Hillmen P, Muus P, Röth A, Elebute MO, Risitano AM, Schrezenmeier H, Szer J, Browne P, Maciejewski JP, Schubert J, Urbano-Ispizua A, de Castro C, Socié G, Brodsky RA: Long-term safety and efficacy of sustained eculizumab treatment in patients with paroxysmal nocturnal haemoglobinuria. Br J Haematol 2013;162:62-73.

78 Keating GM: Eculizumab: a review of its use in atypical haemolytic uraemic syndrome. Drugs 2013;73:2053-2066.

79 Barilla-Labarca ML, Toder K, Furie R: Targeting the complement system in systemic lupus erythematosus and other diseases. Clin Immunol 2013;148:313-321. 